Feature article

\title{
Charge separation promoted by phase junctions in photocatalysts
}

\author{
Yi Ma ${ }^{\mathrm{a}, \mathrm{b}}$, Xiuli Wang a,b, Can Li ${ }^{\mathrm{a}, \mathrm{b}, *}$ \\ a State Key Laboratory of Catalysis, Dalian Institute of Chemical Physics, Chinese Academy of Sciences, Dalian 116023, Liaoning, China \\ ${ }^{\mathrm{b}}$ Dalian National Laboratory for Clean Energy, Dalian 116023, Liaoning, China
}

\section{A R T I C L E I N F O}

\section{Article history:}

Received 9 April 2015

Accepted 22 April 2015

Published 20 xxxxxx 2015

\section{Keywords:}

Photocatalysis

Phase-junction

Charge separation

Solar energy

Titanium oxide

\begin{abstract}
A B S T R A C T
Since the 1980s, photocatalysis research has expanded at an unexpected rate. Fabrication of phase junctions has proved to be an effective method to enhance photocatalytic performance. As a model photocatalyst, titanium dioxide $\left(\mathrm{TiO}_{2}\right)$ has been extensively studied. This feature article mainly reviews the study on $\mathrm{TiO}_{2}$ surface phase junctions, including the characterization of the surface phases of $\mathrm{TiO}_{2}$, the use of anatase: rutile $\mathrm{TiO}_{2}$ phase junctions in photocatalytic hydrogen production, and the current understanding of how $\mathrm{TiO}_{2}$ phase junctions work in photocatalysis. The surface structure of $\mathrm{TiO}_{2}$ can be well characterized by ultraviolet (UV) Raman spectroscopy, unlike X-ray diffraction and visible Raman spectroscopy. Based on these results, the mechanism of phase transformation processes of $\mathrm{TiO}_{2}$ was clearly identified. The infrared (IR) spectra of probe molecules $\mathrm{CO}$ and $\mathrm{CO}_{2}$ on $\mathrm{TiO}_{2}$ further characterized the surface structure of $\mathrm{TiO}_{2}$, strongly supporting the UV Raman results. Furthermore, the typical visible emission of anatase and near-infrared emission of the rutile phase of $\mathrm{TiO}_{2}$ make photoluminescence (PL) a suitable technique to characterize the surface phase structure of $\mathrm{TiO}_{2}$. PL can also provide information about the carrier dynamics of $\mathrm{TiO}_{2}$ in photocatalysis. Because of the surface phase junction formed between anatase and rutile, the mixed-phase structure of $\mathrm{TiO}_{2}$ exhibits a superior $\mathrm{H}_{2}$ production activity to those of pure anatase or rutile phase. The activity of Degussa $\mathrm{P} 25 \mathrm{TiO}_{2}$ can be further increased by three to five times by tuning the phase structure through thermal treatment. Moreover, the phase transformation of $\mathrm{TiO}_{2}$ from anatase to rutile can be controlled by surface modification with $\mathrm{Na}_{2} \mathrm{SO}_{4}$, resulting in catalysts with activity six times higher than that of P25. High-resolution transmission electron microscopy provided a clear phase-junction image of $\mathrm{TiO}_{2}$, which showed atomic contact at the interface of the phase junction. The mechanism of phase junctions improving photocatalytic performance was investigated by time-resolved spectroscopic techniques. The charge transfer process across the anatase: rutile phase junction was confirmed by the results of time-resolved IR measurements, and electron transfer from anatase to rutile phases is proposed to occur in mixed-phase $\mathrm{TiO}_{2}$. These studies on the phase junctions of $\mathrm{TiO}_{2}$ improve our understanding of photocatalysis and may inspire new ideas for the design of promising photocatalytic systems.
\end{abstract}

(C) 2015, Dalian Institute of Chemical Physics, Chinese Academy of Sciences. Published by Elsevier B.V. All rights reserved.

\section{Introduction}

As a promising strategy to address environmental and en- ergy issues, photocatalysis is attracting increasing attention [1-3]. Though extensive research on photocatalysis has been conducted, the crucial factors determining the efficiency of

\footnotetext{
*Corresponding author. Tel: +86-411-84379070; Fax: +86-411-84694447; E-mail: canli@dicp.ac.cn This work was supported by the National Natural Science Foundation of China (21203185); the National Basic Research Program of China (973 program, 2014CB239403). 
photocatalysis are still not well understood. Usually, photocatalytic reactions involve three major steps: (1) generation of electron-hole pairs on a semiconductor by absorption of photons with energy equal to or greater than its bandgap; (2) separation of electron-hole pairs and migration of these charge carriers to the surface of the semiconductor; (3) surface reduction and oxidation reactions involving electrons and holes, respectively, at the semiconductor surface. These three steps correspond to the three crucial factors of light absorption, charge separation and reaction kinetics. Among these, charge separation is the most complicated and important step.

Among semiconductor photocatalysts, $\mathrm{TiO}_{2}$ is the earliest and most extensively investigated photocatalyst because it is cheap, stable, nontoxic, and environmentally friendly. Since the work by Fujishima and Honda published in 1972 [4], research on $\mathrm{TiO}_{2}$ has dramatically increased and been extended to applications in environmental purification, self-cleaning, water splitting, $\mathrm{CO}_{2}$ reduction, organic synthesis, and solar cells. An interesting phenomenon of $\mathrm{TiO}_{2}$ is that the highest activity is usually not obtained for its two major crystalline forms, anatase and rutile, but from samples with a mixture of anatase and rutile phases. $\mathrm{P} 25$, a commercial $\mathrm{TiO}_{2}$ material with mixed anatase and rutile phases, is the best example of this phenomenon. This produces questions about the intrinsic qualities that affect photocatalytic activity, and the step that the anatase: rutile mixed phase promotes, which need to be answered. Recently, the anatase:rutile mixed phase structures of $\mathrm{TiO}_{2}$ have been systematically investigated [5-9]. The formation of anatase: rutile surface phase junctions has been confirmed, and is regarded as the main factor inducing the high photocatalytic activity of $\mathrm{TiO}_{2}$ with mixed phase structure because of its excellent charge separation ability.

In this feature article, some sophisticated techniques and how they are used to characterize the surface phase structure of $\mathrm{TiO}_{2}$ are first introduced. Then, research on the discovery of anatase: rutile $\mathrm{TiO}_{2}$ phase junctions and how this concept has directed subsequent investigations is reviewed. Finally, the investigation of phase junctions by time-resolved mid-infrared (IR) spectroscopy to examine the mechanism behind its charge separation ability is discussed. This feature article also covers some other important factors related to the performance of $\mathrm{TiO}_{2}$ photocatalysts.

\section{Characterization of $\mathrm{TiO}_{2}$ with different phase structures}

As mentioned above, the phase structure of $\mathrm{TiO}_{2}$ strongly affects its photocatalytic activity. Numerous techniques have been used to characterize the structure of $\mathrm{TiO}_{2}$, such as X-ray diffraction (XRD), transmission electron microscopy (TEM), and Raman and Fourier transform infrared (FT-IR) spectroscopies. Herein, three typical spectroscopic techniques used to investigate the phase structure of $\mathrm{TiO}_{2}$ are introduced. The unique features of these techniques can further our understanding of the structure and even the carrier dynamics of $\mathrm{TiO}_{2}$.

In heterogeneous catalysis, reactions take place on the surface of the catalysts. Therefore, the catalytic performance largely depends on the surface properties of the catalyst. Ultraviolet (UV) Raman spectroscopy has recently been proved a powerful tool in materials science [10], mainly because it can efficiently avoid the interference from fluorescence in visible Raman spectra and simultaneously enhance the Raman signal because of its short wavelength and the resonance Raman effect [11]. Here, UV Raman spectroscopy is used to monitor the phase transformation process of $\mathrm{TiO}_{2}$ [6]. Because $\mathrm{TiO}_{2}$ strongly absorbs UV light, UV Raman spectroscopy is more sensitive to the surface structure of $\mathrm{TiO}_{2}$ than XRD and visible Raman spectroscopy. The results obtained from these techniques for the phase transformation process of $\mathrm{TiO}_{2}$ disagree, which indicates that the surface region of anatase phase detected by UV Raman spectra is more stable at higher temperatures than that in bulk $\mathrm{TiO}_{2}$ detected by XRD and visible Raman spectra. TEM images show that the phase transformation process of $\mathrm{TiO}_{2}$ is accompanied by growth of anatase particles. If the surface of anatase particles is covered by dispersed lanthanum oxide $\left(\mathrm{La}_{2} \mathrm{O}_{3}\right)$, the phase transformation can be efficiently restrained [6]. Based on these results, a clear phase transformation mechanism for $\mathrm{TiO}_{2}$ is shown in Fig. 1. With increasing temperature, the phase transformation process of $\mathrm{TiO}_{2}$ initiates from the surface of integrated anatase particles. The bulk of the new

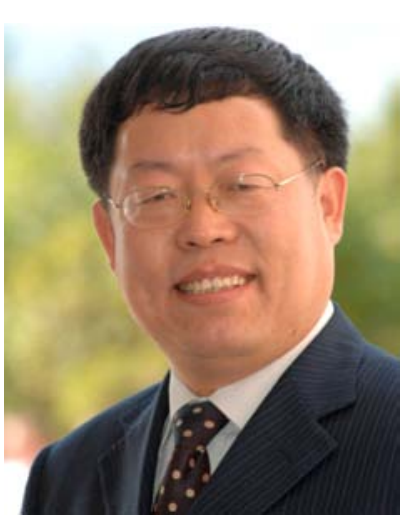

Can Li (Dalian Institute of Chemical Physics, Chinese Academy of Science) received the Catalysis Achievement Award (the Dayu Zhang Award) in 2014, which was presented by The Catalysis Society of China. Professor Can Li received his Ph.D. degree in Physical Chemistry from Dalian Institute of Chemical Physics, Chinese Academy of Sciences, in 1989, and he joined the same institute and was promoted to full professor in 1993. He did postdoctoral research on catalysis and UV Raman spectroscopy at Northwestern University and was visiting professor at Lehigh University, the University of Liverpool, and The Queensland University, and he was awarded the JSPS Professor at Waseda University, Tokyo University of Technology, and Hokkaido University. He was an invited professor at Université Pierre et Marie Curie, Paris VI. He was the President of the International Association of Catalysis Societies (2008-2012). Currently, he is the director of the State Key Laboratory of Catalysis, and the director of the Dalian National Laboratory for Clean Energy (DNL). His research interests include (1) UV Raman spectroscopy and ultrafast spectroscopy; (2) environmental catalysis and green catalysis; (3) heterogeneous asymmetric catalysis; and (4) solar energy utilization based on photocatalysis, photoelectrocatalysis and photovoltaic cells. He has published more than 500 peer-reviewed papers with over 10000 citations. 


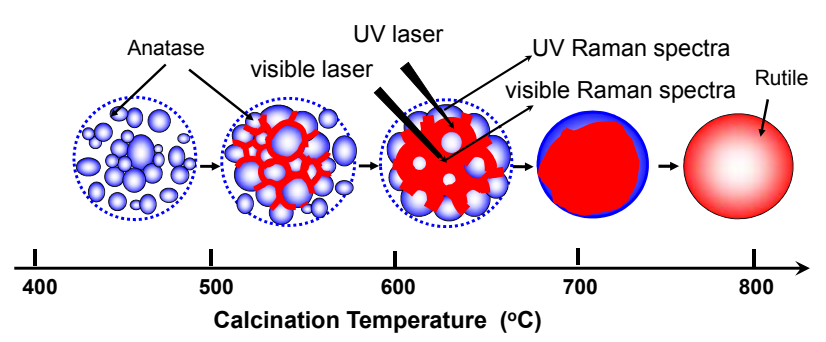

Fig. 1. The proposed mechanism for the phase transformation of $\mathrm{TiO}_{2}$ at elevated temperatures Reprinted with the permission from Ref. [11]. Copyright 2009 Editorial Office of Chinese Journal of Catalysis, Dalian Institute of Chemical Physics, Chinese Academy of Sciences.

larger particle then gradually transforms to rutile phase. Finally, the transformation is completed within the entire particle.

Actually, the mechanism of phase transformation of $\mathrm{TiO}_{2}$ is more complicated than one simple process. The following studies show that phase transformation of $\mathrm{TiO}_{2}$ is a size-dependent process, where size determines not only the onset transition temperature but also the nucleation performance [7]. UV Raman spectroscopy is used to determine the variation of the surface phase structure of $\mathrm{TiO}_{2}$, while XRD is used to examine the variation of the bulk. As depicted in Fig. 2, the phase transformation temperature increases with the initial particle size. For small particles $(<60 \mathrm{~nm})$, rutile nucleates at the interfaces between contacting anatase grains. Conversely, for large particles ( $>60 \mathrm{~nm}$ ), the free surface, interface and bulk of anatase $\mathrm{TiO}_{2}$ can all function as rutile nucleation sites. UV Raman spectroscopy allows the difference between the surface and bulk transformation processes of $\mathrm{TiO}_{2}$ to be distinguished.

Although UV Raman spectroscopy can in principle provide more information about surfaces than the bulk for materials that absorb UV light, direct evidence of surface behavior is still needed. Therefore, IR spectra of probe molecules adsorbed on $\mathrm{TiO}_{2}$ were used to support the results obtained from UV Raman spectroscopy [12]. Such FT-IR spectroscopy is more complicated than UV Raman spectroscopy but undoubtedly a surface

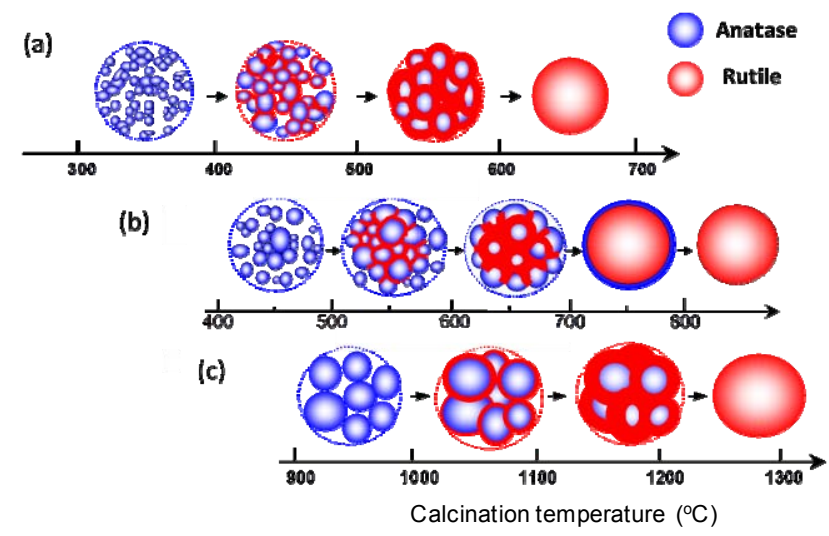

Fig. 2. Proposed mechanisms for the phase transformation of $\mathrm{TiO}_{2}$ with various particle size (a) smaller than $10 \mathrm{~nm}$; (b) in the range of 10-60 $\mathrm{nm}$; (c) larger than $60 \mathrm{~nm}$. Reprinted with the permission from Ref. [11] Copyright 2009 Editorial Office of Chinese Journal of Catalysis, Dalian Institute of Chemical Physics, Chinese Academy of Sciences. technique. Because of the different surface properties of anatase and rutile $\mathrm{TiO}_{2}$, carbon monoxide (CO) and carbon dioxide $\left(\mathrm{CO}_{2}\right)$ can exhibit different adsorption behavior on these two phases. For example, $\mathrm{CO}$ is weakly adsorbed on $\mathrm{Ti}^{4+}$ ions of the anatase phase, but hardly adsorbed on the rutile phase at room temperature. Moreover, $\mathrm{CO}_{2}$ mainly adsorbs as bidentate carbonate on the anatase phase, but adsorbs as a bicarbonate species on the rutile phase. Therefore, IR spectra of $\mathrm{CO}$ and $\mathrm{CO}_{2}$ adsorbed on $\mathrm{TiO}_{2}$ can reveal its surface structure. The IR spectra agreed well with the findings of UV Raman spectra, but differed from those of XRD [12], further confirming that UV Raman spectroscopy is a surface-sensitive technique for $\mathrm{TiO}_{2}$.

Photoluminescence (PL) spectroscopy is used to characterize the excited electronic states of materials. For semiconductor materials, PL spectroscopy can supply meaningful information about crystal structures, defect states and charge carrier dynamics. As an indirect wide-band-gap semiconductor, $\mathrm{TiO}_{2}$ always displays trap-related luminescence bands, while the band-edge luminescence is difficult to observe. The position and intensity of PL from $\mathrm{TiO}_{2}$ strongly depends on its crystal structure, particle size, dopants, impurities, annealing temperature and atmospheric environment during crystallization, and the ambient temperature and atmosphere during the PL measurements. The main luminescence features of $\mathrm{TiO}_{2}$ are broad structureless emission bands. Anatase $\mathrm{TiO}_{2}$ has a visible emission, which is attributed to self-trapped excitons [13], oxygen vacancies [14], defect sites [15], impurities or reduced metal ions [16], etc. Meanwhile, rutile $\mathrm{TiO}_{2}$ exhibits a near-infrared (NIR) luminescence that is assigned to $\mathrm{Cr}^{3+}$ impurities [17], interstitial $\mathrm{Ti}^{3+}$ ions [16], intermediate species generated during the photooxidation reaction of water [18], or the intrinsic defects of rutile $\mathrm{TiO}_{2}$ [19].

The PL characteristics of $\mathrm{TiO}_{2}$ during phase transformation, in combination with UV Raman spectroscopy, reveal the progression of $\mathrm{TiO}_{2}$ phase structure [20]. Anatase $\mathrm{TiO}_{2}$ exhibits a visible emission band centered at about $505 \mathrm{~nm}$, while rutile $\mathrm{TiO}_{2}$ has a NIR emission band centered at about $835 \mathrm{~nm}$. Comparison of the PL and UV Raman spectra of $\mathrm{TiO}_{2}$ confirmed that the luminescence band position of $\mathrm{TiO}_{2}$ is related to its crystalline structure. Namely, the visible emission band is related to anatase structure, while the NIR emission band is associated with rutile structure (Fig. 3). The visible emission of anatase and the NIR emission of the rutile phase both exhibit extremely long lifetimes of up to milliseconds under weak excitation conditions [21]. The power-law decay of the luminescence indicates that PL from both anatase and rutile $\mathrm{TiO}_{2}$ has a close relation with trap states. The visible emission band of the anatase phase is assigned to donor-acceptor recombination, with mainly oxygen vacancies and hydroxyl groups as donor and acceptor sites, respectively. The NIR luminescence from rutile $\mathrm{TiO}_{2}$ originates from the recombination of trapped electrons with free holes (Fig. 4).

Based on the relationship between PL bands and the crystalline structure of $\mathrm{TiO}_{2}$, PL measurements were used to study the role of trap states of $\mathrm{TiO}_{2}$ in photocatalysis. The visible emission band of anatase $\mathrm{TiO}_{2}$ is easily quenched by the deposition of Pt on its surface, while the NIR luminescence band of 


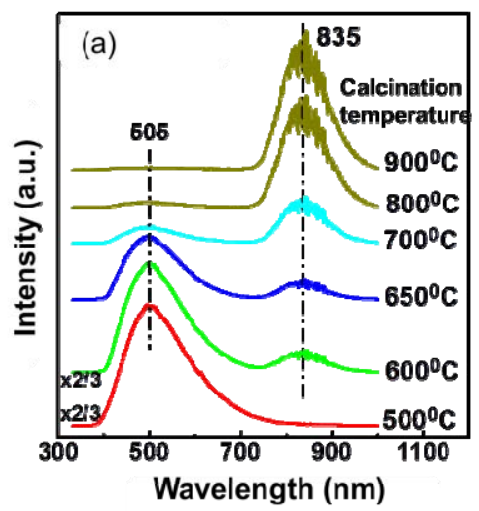

(b)

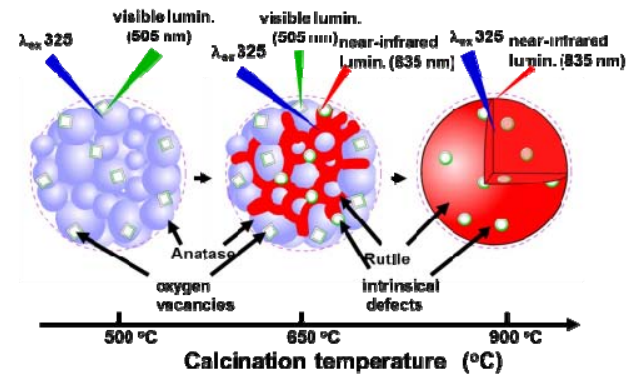

Fig. 3. (a) Photoluminescence spectra of $\mathrm{TiO}_{2}$ calcined at different temperatures. (b) Schematic illustration of the photoluminescence evolution with the phase transformation of $\mathrm{TiO}_{2}$. Reprinted with the permission from Ref. [20]. Copyright 2007 American Chemical Society.

(a)

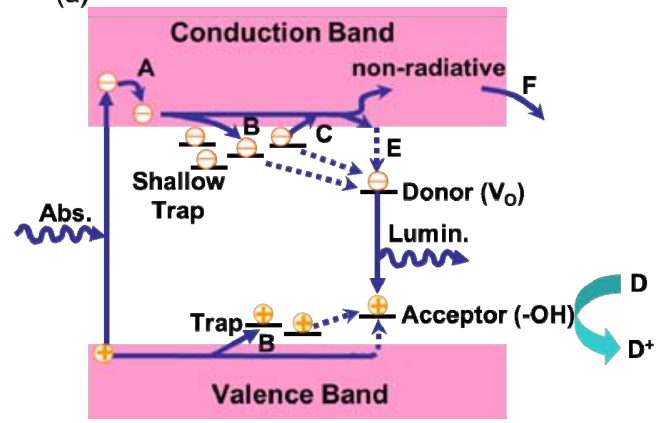

(b)

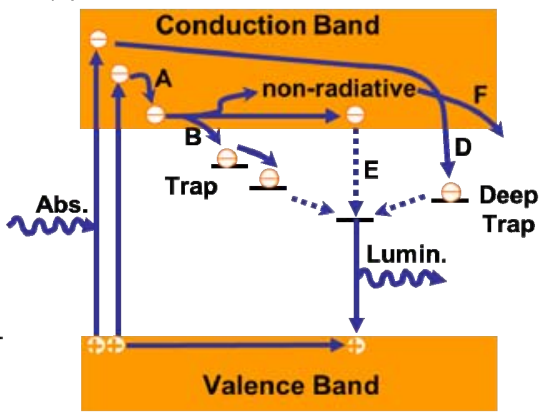

Fig. 4. Schematic illustration of relaxation processes of the photogenerated carriers in anatase (a) and rutile $\mathrm{TiO}_{2}$ (b). (A) Electrons quenched to the bottom of the conduction band, (B) carriers captured by traps, (C) thermal excitation from traps, (D) electrons captured directly by deep traps, (E) carriers relax to luminescent sites, (F) nonradiative recombination process. Reprinted with the permission from Ref. [21]. Copyright 2010 Royal Society of Chemistry. Acknowledgements to be used by RSC authors.

rutile $\mathrm{TiO}_{2}$ is not [20]. The lifetimes of anatase $\mathrm{TiO}_{2}$ shortened considerably after it was treated under vacuum at $150{ }^{\circ} \mathrm{C}$ for 1 $h$, because of the desorption of $\mathrm{H}_{2} \mathrm{O}$ molecules and change of surface hydroxyl groups [21]. In contrast, the luminescence decay profiles of NIR luminescence from rutile $\mathrm{TiO}_{2}$ were not affected by the same thermal treatment. These results suggest that the trapped carriers in anatase $\mathrm{TiO}_{2}$ may be involved in the photocatalytic reactions and the slow decay processes may be beneficial for photocatalysis performance, while the trapped carriers in rutile $\mathrm{TiO}_{2}$ may be less likely to participate in photocatalytic reaction processes.

\section{Photocatalytic $\mathrm{H}_{2}$ generation on $\mathrm{TiO}_{2}$ with phase junctions}

The above characterization results provide us with an opportunity to better understand the phase transformation mechanism and structure of $\mathrm{TiO}_{2}$, which may in turn allow us to optimize the performance of $\mathrm{TiO}_{2}$ in photocatalysis by revealing what we can do to improve its activity. $\mathrm{TiO}_{2}$ samples with different surface and bulk crystalline phases were prepared by thermal treatment of $\mathrm{Ti}(\mathrm{OH})_{4}$ in air from 500 to $800{ }^{\circ} \mathrm{C}$ [5]. The rutile content of the bulk region and anatase content of the surface region were estimated from visible and UV Raman spectra, respectively. Maximum activity was observed for $\mathrm{TiO}_{2}$ samples calcined at $700-750{ }^{\circ} \mathrm{C}$, where the bulk of $\mathrm{TiO}_{2}$ was mostly rutile while the surface was a mixture of anatase and rutile phases. When the calcination temperature was further increased to $800{ }^{\circ} \mathrm{C}$, the anatase phase at the surface region was completely transformed to rutile and correspondingly the photocatalytic activity decreased dramatically. These results show that the presence of anatase phase on the surface of rutile particles can maintain high photocatalytic activity. This led to the concept of surface phase junctions formed between anatase and rutile, which is proposed to facilitate charge separation at the surface of $\mathrm{TiO}_{2}$. To further clarify this concept, anatase nanoparticles were deposited on rutile particles by a wet-impregnation method followed by thermal treatment. As shown in Fig. 5(a), the photocatalytic activity of the samples increased with the amount of anatase nanoparticles up to a certain threshold. However, when the amount of anatase was increased above the threshold, the activity decreased. This is because too many anatase nanoparticles will decrease the area of phase junctions exposed on the surface of $\mathrm{TiO}_{2}$. The high-resolution transmission electron microscopy (HRTEM) image in Fig. 5(b) reveals that the loaded anatase nanoparticles 
(a)

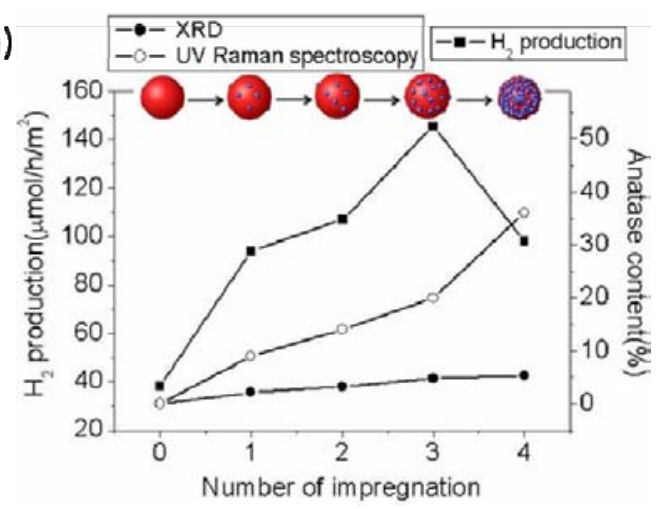

(b)

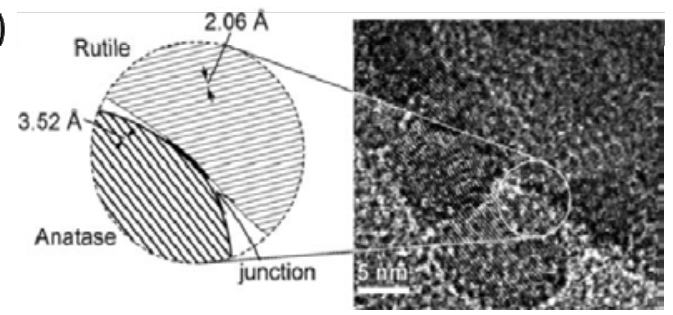

Fig. 5. (a) Photocatalytic activities for $\mathrm{H}_{2}$ evolution of rutile $\mathrm{TiO}_{2}$ loaded with increasing amount of anatase nanoparticles. (b) Surface phase-junction formed between anatase and rutile. Reprinted with permission from Ref. [5]. Copyright 2008 Wiley-VCH.

closely contacted with rutile particles to form phase junctions.

Degussa P25 is composed of approximately $80 \%$ anatase and $20 \%$ rutile phases and is a benchmark type of $\mathrm{TiO}_{2}$ because of its high photocatalytic activity. The synergistic effect between anatase and rutile phases is considered the origin of its excellent performance. The activity of P25 can be further increased via elaborately controlled thermal treatment [8], which transforms P25 to a catalyst with optimized anatase-rutile structure. As shown in Fig. 6, in the photocatalytic reforming of methanol, propanetriol and glucose, the overall activity of P25 can be enhanced up to 3-5 times by thermal treatment. These results also show that the degree of crystallization is not the major cause of the high photocatalytic activity of thermally treated P25, because further increasing the temperature during thermal treatment did not increase its photocatalytic activity. Therefore, the optimized phase structure obtained by carefully controlled thermal treatment of P25 is the main contributor to the enhancement of its photocatalytic activity.

As the importance of phase junctions has been realized, new methods to prepare $\mathrm{TiO}_{2}$ that allow phase control have attracted increasing attention [22]. The phase transformation of $\mathrm{TiO}_{2}$ from anatase to rutile can be restrained by surface modification with $\mathrm{Na}_{2} \mathrm{SO}_{4}$ [9]. When the content of $\mathrm{SO}_{4}{ }^{2-}$ in $\mathrm{TiO}_{2}$ was increased from 0 to $3 \mathrm{wt} \%$, the percentage of anatase in the surface region increased from $2 \%$ to $75 \%$. It should be mentioned that this method can be used to prepare $\mathrm{TiO}_{2}$ with different phase structures at the same temperature, which facilitates comparison of these catalysts. Compared with P25, the as-prepared $\mathrm{TiO}_{2}-\mathrm{SO}_{4}{ }^{2-}$ samples showed activities for $\mathrm{H}_{2}$ production via photocatalytic reforming of methanol that were up to six times higher. TEM images revealed that small anatase particles were dispersed on the edge of large rutile particles to form the junction structure. Because the junction formed during the phase transformation process, intimate contact formed between anatase and rutile phases. The example in Fig. 7 shows that the junction is formed at the atomic level, which consequently facilitates charge transfer. Besides $\mathrm{Na}_{2} \mathrm{SO}_{4}$, other additives such as $\mathrm{NaNO}_{3}, \mathrm{NaHCO}_{3}, \mathrm{Na}_{3} \mathrm{PO}_{4}, \mathrm{Na}_{2} \mathrm{SiO}_{3}$, and $\mathrm{Na}_{2} \mathrm{MoO}_{4}$ can also be used to control the phase of $\mathrm{TiO}_{2}$ [23]. However, the photocatalytic activity of $\mathrm{TiO}_{2}$ is not only influenced by its phase structure, but also by its surface chemical properties. Therefore, poorer performance might be obtained using certain control agents even when a perfect phase-junction structure is formed.

Since the anatase:rutile phase-junction concept was proposed, it has become a guideline for the preparation of $\mathrm{TiO}_{2}$ nanoparticles [24,25], nanorod arrays [26], and nanobelts [27]. Similar junctions, such as anatase: $\mathrm{TiO}_{2}(\mathrm{~B})$ phase junctions [28-33], and even other semiconductors such as the $\alpha: \beta$ phase
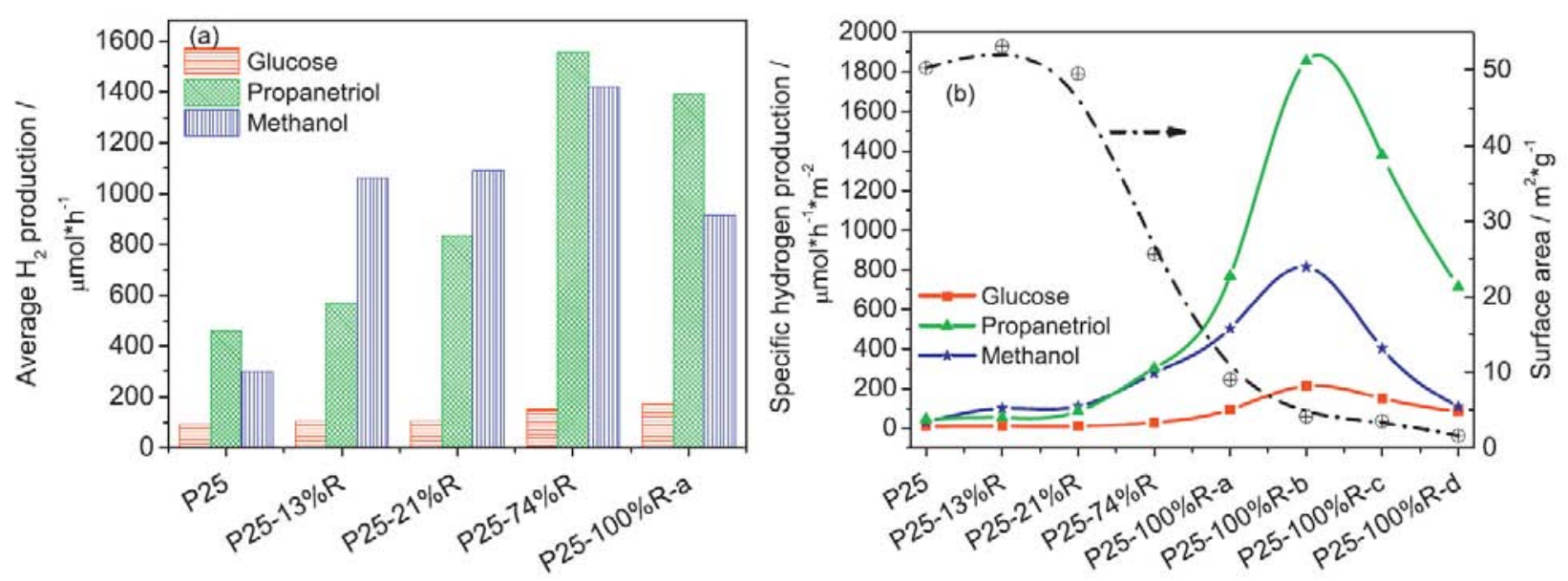

Fig. 6. (a) Average hydrogen production in photocatalytic reforming methanol, propanetriol and glucose and (b) surface-specific photocatalytic activity for hydrogen production in photocatalytic reforming methanol on Pt/P25- $w \% \mathrm{R}$ photocatalysts (where $w$ indicates the rutile content estimated by XRD. For P25-100\%R-a, b, c, d photocatalysts, where a, b, c and d indicate different treatment conditions), the surface areas of P25-w\%R photocatalysts are also displayed (dash dot). Reprinted with the permission from Ref. [8]. Copyright 2011 Elsevier. 


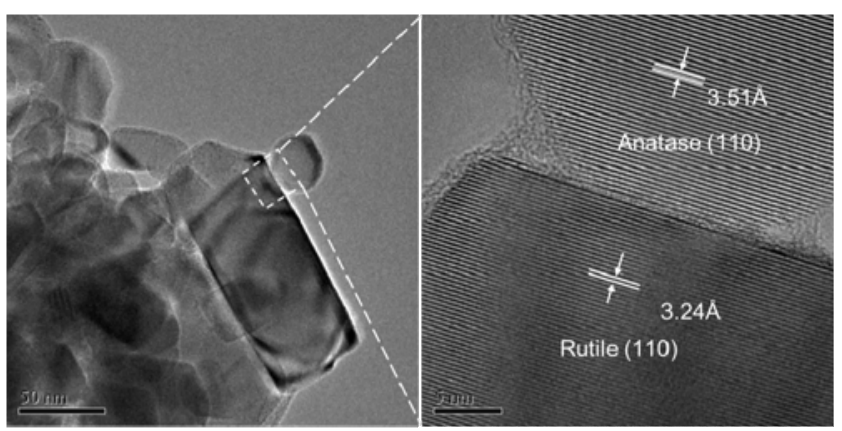

Fig. 7. Atomic level contact of anatase: rutile phase-junction. Reprinted with the permission from Ref. [9]. Copyright 2012 Royal Society of Chemistry. Acknowledgements to be used by RSC authors.

junction of $\mathrm{Ga}_{2} \mathrm{O}_{3}$, have since been successfully used in photocatalytic reactions [34].

\section{Other aspects of $\mathrm{TiO}_{2}$-based photocatalysis}

Besides phase junctions, some other aspects that affect the performance of $\mathrm{TiO}_{2}$ photocatalysts, such as cocatalysts, by-products, and reaction environment, should also be considered. Recently, a synergetic effect of dual cocatalysts $\mathrm{Pd}-\mathrm{IrO}_{x}$ loaded on $\mathrm{TiO}_{2}$ in photocatalytic $\mathrm{H}_{2}$ production reactions was found [35]. $\mathrm{Pd}$ and $\mathrm{IrO}_{x}$ particles located close together showed better performance than separated ones, which is quite different from the common situation. Undesired by-product $\mathrm{CO}$ obtained from the reactions of photocatalytic $\mathrm{H}_{2}$ production via reforming of methanol or other biomass derivatives is always a problem, because there is a very strict CO limit that must be met for fuel cell applications [36]. CO-suppressing methods such as addition of a small amount of inorganic anions [37], using a smaller size of cocatalyst [38], and controlling the surface acidity of $\mathrm{TiO}_{2}[8,9,23]$ have been developed.

Meanwhile, the overall water splitting reaction is seldom stoichiometric on $\mathrm{TiO}_{2}$. However, it has been found that the addition of $\mathrm{Cl}^{-}$can facilitate the water splitting reaction [39]. $\mathrm{Cl}^{-}$ can not only trigger $\mathrm{O}_{2}$ evolution, but also promote the $\mathrm{H}_{2}$ evolution simultaneously. Besides overall water splitting, $\mathrm{TiO}_{2}$-based catalysts can also be used to convert biomass to value-added chemicals. For example, transformation of glycerol to hydroxyacetaldehyde [40] and glucose to sugar aldose [41] have been achieved recently, extending the scope of $\mathrm{TiO}_{2}$ photocatalysts.

\section{Mechanism of charge transfer across an anatase: rutile $\mathrm{TiO}_{2}$ junction}

Anatase:rutile mixed-phase $\mathrm{TiO}_{2}$ is more active than anatase or rutile $\mathrm{TiO}_{2}$ in photocatalytic reactions. It has been proposed that anatase: rutile phase junctions are responsible for the improved photoactivity. Such phase junctions are supposed to increase charge separation and then prolong charge lifetime to facilitate photocatalytic reactions. Many researchers are devoted to confirming the role of anatase:rutile phase junctions in photocatalysis both experimentally and theoretically.

Based on electron spin resonance experiments, Hurum et al.
[42] claimed that the electron transfer from rutile to anatase occurred at the transition points between anatase and rutile in Degussa P25, while Komaguchi et al. [43] proposed that photoinduced electron transfer proceeded from anatase to rutile in partially reduced P25. Kawahara et al. [44] suggested that the high photocatalytic activity of P25 was mainly caused by the increase in charge separation efficiency resulting from interfacial electron transfer from anatase to rutile phases based on TEM analysis of patterned $\mathrm{TiO}_{2}$ (anatase) $/ \mathrm{TiO}_{2}$ (rutile) bilayer-type photocatalysts.

Time-resolved spectroscopic techniques have also been used to study mixed-phase $\mathrm{TiO}_{2}$. Carneiro et al. [45] claimed that photogenerated holes were captured by rutile in mixed-phase $\mathrm{TiO}_{2}$ according to the results of time-resolved microwave conductance spectroscopy of mixed-phase $\mathrm{TiO}_{2}$. The kinetics of photoinduced electrons in anatase, rutile, and mixed-phase $\mathrm{TiO}_{2}$ have also been studied using time-resolved mid-IR spectroscopy [46], which has been proved to be a powerful tool to monitor the kinetics of photogenerated electrons in semiconductor photocatalysts [47]. It was found that the dynamics of the transient mid-IR absorption of anatase and rutile were different. Anatase showed a transient mid-IR absorption signal, whereas rutile did not display any detectable mid-IR absorption on the microsecond time scale. Based on the relationship between initial mid-IR absorption and phase composition, a charge transfer process across the anatase:rutile phase junction was confirmed, and electron transfer from anatase to rutile was proposed to occur in mixed-phase $\mathrm{TiO}_{2}$ (Fig. 8).

To understand the charge transfer at the interfaces of anatase and rutile phases, the band alignment between anatase and rutile has been calculated theoretically. Kang et al. [48] claimed that the conduction band minimum of anatase was about $0.2 \mathrm{eV}$ higher than that of rutile with similar valence band maxima for anatase and rutile, indicating that electron transfer from anatase to rutile is more likely than vice versa. Conversely, Scanlon et al. [49] reported that a type II staggered band alignment of $0.4 \mathrm{eV}$ existed between anatase and rutile with rutile possessing the higher conduction band minimum, which is beneficial for electron transfer from rutile to anatase.

To date, the direction of charge transfer at anatase:rutile phase junctions and its role in photocatalysis are still debated, even though much work has been done using various techniques as discussed above. These points are still debated because charge-transfer behavior strongly depends on both the phase composition and preparation method of mixed-phase $\mathrm{TiO}_{2}$. Therefore, further work is still required to understand anatase:rutile junctions in greater detail and optimize the photocatalytic performance of $\mathrm{TiO}_{2}$.

\section{Conclusions and perspectives}

In this feature article, characterization techniques used to investigate the phase structure of $\mathrm{TiO}_{2}$ were first introduced, including UV Raman, FT-IR and PL spectroscopies. UV Raman spectroscopy and FT-IR spectroscopy of adsorbed probe molecules provided unique evidence for the surface phase struc- 


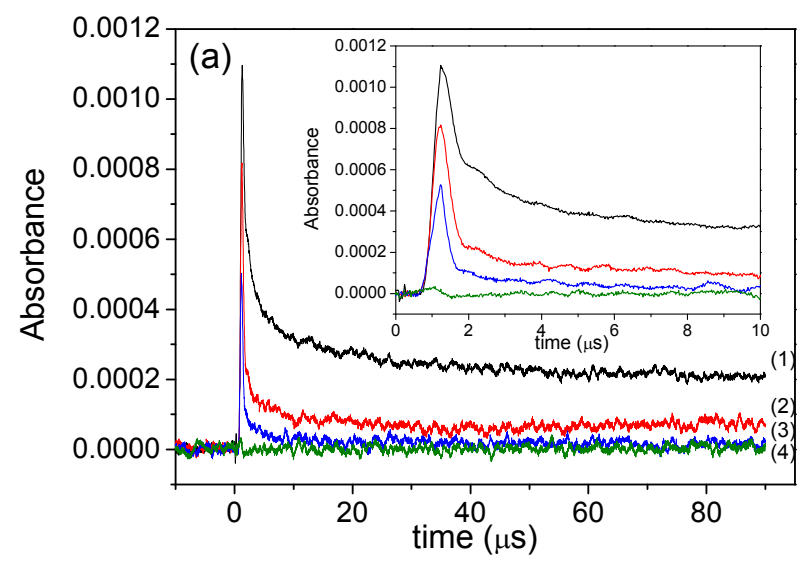

(b)

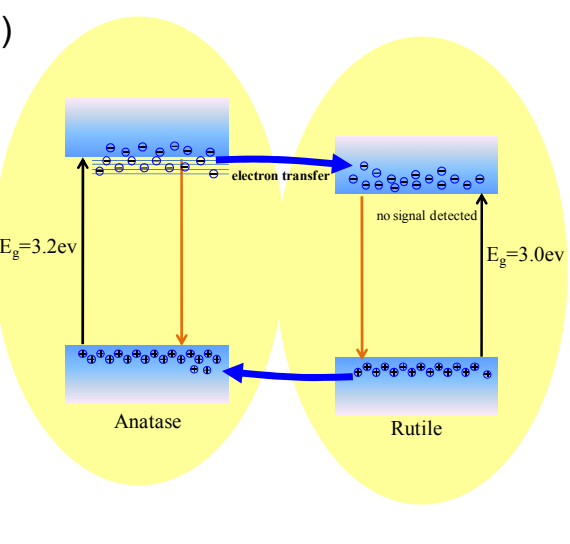

Fig. 8. (a) Transient mid-IR absorption decays of (1) anatase, (2) anatase-rutile mixed phase $\mathrm{TiO}_{2}-600$, (3)anatase-rutile mixed phase $\mathrm{TiO}_{2}-700$, and (4) rutile in a vacuum excited by $355 \mathrm{~nm}$ laser pulse of 6-8 ns duration. (b) Schematic band structure of anatase and rutile under UV light irradiation. Reprinted with the permission from Ref. [50]. Copyright 2014 American Chemical Society.

ture and phase transformation of $\mathrm{TiO}_{2}$. PL spectra not only revealed the phase structure of $\mathrm{TiO}_{2}$ and its emission-related trap states, but also the role of trap states in photocatalysis. The roles of surface phase junctions of $\mathrm{TiO}_{2}$ in photocatalytic $\mathrm{H}_{2}$ evolution reactions were then reviewed in detail. The presence of anatase:rutile surface phase junctions can increase the photocatalytic activity of $\mathrm{TiO}_{2}$-based materials, which is ascribed to efficient charge separation between anatase and rutile phases. Some other factors that can affect the performance of photocatalysts in different ways, such as cocatalysts, by-products, and reaction environment, were then briefly introduced. Finally, the mechanism of charge transfer at anatase:rutile phase junctions was discussed. Electron transfer from anatase to rutile $\mathrm{TiO}_{2}$ was confirmed by time-resolved mid-IR spectroscopy.

Conversion of solar energy into fuels via photocatalysis is considered a promising way to solve energy and environmental issues. As a benchmark photocatalyst, $\mathrm{TiO}_{2}$ is the most widely investigated semiconductor photocatalyst. However, the majority of research in this field still focuses on environmental photocatalysis, mainly involving the degradation of pollutants such as organic wastes and dyes. Increasing attention is now being paid to fuel generation reactions such as overall water splitting and $\mathrm{CO}_{2}$ reduction. However, the photocatalytic $\mathrm{H}_{2}$ production in the presence of sacrificial reagent achieved to date cannot be considered true water splitting. Despite this, these reactions can provide meaningful insights into the mechanism of photocatalytic reactions to aid design of improved photocatalysts.

It should be mentioned that $\mathrm{TiO}_{2}$ may not be a promising catalyst for photocatalytic water splitting reaction because of its intrinsic properties, such as only UV light absorption. It is also not expected that a great breakthrough on $\mathrm{TiO}_{2}$ can be achieved in the near future. However, strategies such as extending the light absorption range of $\mathrm{TiO}_{2}$ and combination with other materials to construct a photocatalyst system may overcome some disadvantages of $\mathrm{TiO}_{2}$ itself. Furthermore, $\mathrm{TiO}_{2}$ is still an ideal model for understanding the mechanisms of photocatalytic processes, which will help in the design and construction of more efficient photocatalyst systems. Therefore, research on $\mathrm{TiO}_{2}$ will continue.

\section{References}

[1] Ma Y, Wang X L, Jia Y S, Chen X B, Han H X, Li C. Chem Rev, 2014, 114: 9987

[2] Kudo A, Miseki Y. Chem Soc Rev, 2009, 38: 253

[3] Yang J H, Wang D G, Han H X, Li C. Acc Chem Res, 2013, 46: 1900

[4] Fujishima A, Honda K. Nature, 1972, 238: 37

[5] Zhang J, Xu Q, Feng Z C, Li M J, Li C. Angew Chem Int Ed, 2008, 47: 1766

[6] Zhang J, Li M J, Feng Z C, Chen J, Li C. J Phys Chem B, 2006, 110: 927

[7] Zhang J, Xu Q, Li M J, Feng Z C, Li C.J Phys Chem C, 2009, 113: 1698

[8] Xu Q, Ma Y, Zhang J, Wang X L, Feng Z C, Li C. J Catal, 2011, 278: 329

[9] Ma Y, Xu Q, Zong X, Wang D G, Wu G P, Wang X, Li C. Energy Environ Sci, 2012, 5: 6345

[10] Fan F T, Feng Z C, Li C. Chem Soc Rev, 2010, 39: 4794

[11] Fan F T, Xu Q, Xia H A, Sun K J, Feng Z C, Li C. Chin J Catal (范峰滔, 徐倩, 夏海岸, 孙科举, 冯兆池, 李灿, 催化学报), 2009, 30: 717

[12] Su W G, Zhang J, Feng Z C, Chen T, Ying P L, Li C. J Phys Chem C, 2008, 112: 7710

[13] Tang H, Berger H, Schmid P E, Levy F, Burri G. Solid State Commun, 1993, 87: 847

[14] Mochizuki S, Shimizu T, Fujishiro F. Physica B-Condensed Matter, 2003, 340: 956

[15] Zhang W F, Zhang M S, Yin Z, Chen Q. Appl Phys B, 2000, 70: 261

[16] Fernandez I, Cremades A, Piqueras J. Semicond Sci Technol, 2005, 20: 239

[17] Grabner L, Stokowsk S E, Brower W S. Phys Rev B, 1970, 2: 590

[18] Nakato Y, Akanuma H, Magari Y, Yae S, Shimizu J I, Mori H. J Phys Chem B, 1997, 101: 4934

[19] Poznyak S K, Sviridov V V, Kulak A I, Samtsov M P. J Electroanal Chem, 1992, 340: 73

[20] Shi J Y, Chen J, Feng Z C, Chen T, Lian Y X, Wang X L, Li C. J Phys Chem C, 2007, 111: 693 


\title{
Graphical Abstract
}

Chin. J. Catal., 2015, 36: 0-0 doi: 10.1016/S1872-2067(15)60874-9

\section{Charge separation promoted by phase junctions in photocatalysts}

Yi Ma, Xiuli Wang, Can Li*

Dalian Institute of Chemical Physics, Chinese Academy of Sciences; Dalian National Laboratory for Clean Energy

Charge separation is an important step in photocatalysis. Construction of phase junctions on semiconductors is a promising strategy to enhance the efficiency of charge separation, inspiring the design of future photocatalysts.

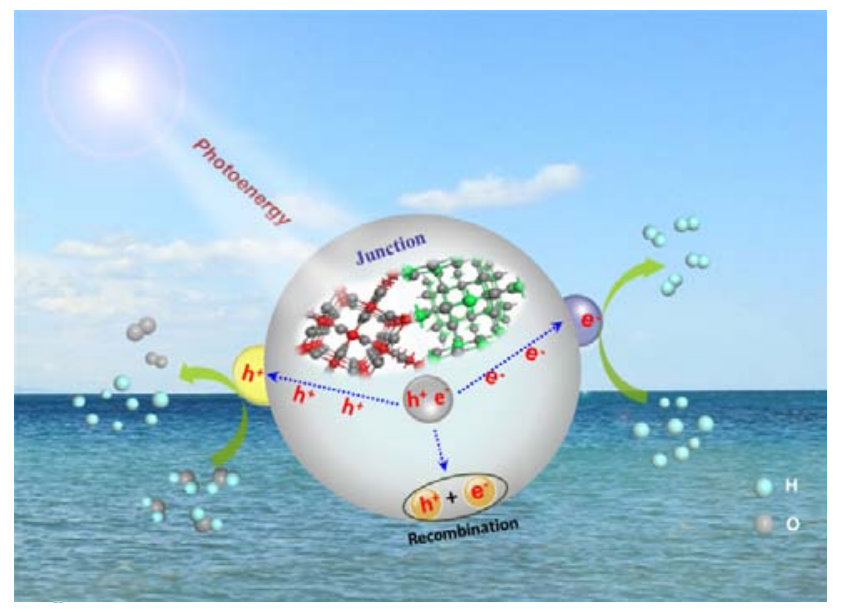

[38] Wu G P, Chen T, Su W G, Zhou G H, Zong X, Lei Z B, Li C. Int J Hydrogen Energy, 2008, 33: 1243

[39] Huang L, Li R G, Chong R F, Liu G, Han J F, Li C. Catal Sci Technol, 2014, 4: 2913

[40] Chong R F, li J, Zhou X, Ma Y, Yang J X, Huang L, Han H X, Zhang F X, Li C. Chem Commun, 2014, 50: 165

[41] Chong R F, Li J, Ma Y, Zhang B, Han H X, Li C.J Catal, 2014, 314: 101

[42] Hurum D C, Agrios A G, Gray K A, Rajh T, Thurnauer M C. J Phys Chem B, 2003, 107: 4545

[43] Komaguchi K, Nakano H, Araki A, Harima Y. Chem Phys Lett, 2006, 428: 338

[44] Kawahara T, Konishi Y, Tada H, Tohge N, Nishii J, Ito S. Angew Chem Int Edit, 2002, 41: 2811

[45] Carneiro J T, Savenije T J, Moulijn J A, Mul G. J Phys Chem C, 2011, 115: 2211

[46] Shen S, Wang X L, Chen T, Feng Z C, Li C. J Phys Chem C, 2014, 118: 12661

[47] Chen T, Wu G P, Feng Z C, Hu G S, Su W G, Ying P L, Li C. Chin J Catal (陈涛, 吴国鹏, 冯兆池, 胡庚申, 苏伟光, 应品良, 李灿, 催化学报), 2008, 29: 105

[48] Kang J, Wu F M, Li S S, Xia J B, Li J B. J Phys Chem C, 2012, 116: 20765

[49] Scanlon D O, Dunnill C W, Buckeridge J, Shevlin S A, Logsdail A J, Woodley S M, Catlow C R A, Powell M J, Palgrave R G, Parkin I P, Watson G W, Keal T W, Sherwood P, Walsh A, Sokol A A. Nat Mater, 2013, 12: 798

[50] Shen S, Wang X L, Chen T, Feng Z C, Li C.J Phys Chem C, 2014, 118: 12661

[37] Wu G P, Chen T, Zong X, Yan H J, Ma G J, Wang X L, Xu Q, Wang D G, Lei Z B, Li C.J Catal, 2008, 253: 225

\section{表面相结结构在促进光催化电荷分离中的应用}

\author{
马 艺 ${ }^{\mathrm{a}, \mathrm{b}}$, 王秀丽 ${ }^{\mathrm{a}, \mathrm{b}}$, 李 灿 ${ }^{\mathrm{a}, \mathrm{b},{ }^{*}}$ \\ ${ }^{\mathrm{a}}$ 中国科学院大连化学物理研究所催化基础国家重点实验室,辽宁大连 116023

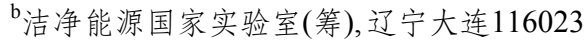

摘要: 二十世纪八十年代以来, 特别是近十年, 光催化研究在利用可再生能源太阳能的道路上飞速发展. 越来越多的研究表明, 相 
结结构的构筑是有效提高半导体光催化剂性能的重要策略. 其中, $\mathrm{TiO}_{2}$ 作为重要的模型光催化剂, 其相关研究成果呈现出指数增 长的趋势. 本综述围绕 $\mathrm{TiO}_{2}$ 模型光催化剂, 主要介绍 $\mathrm{TiO}_{2}$ 表面相结的研究成果, 包括 $\mathrm{TiO}_{2}$ 表面相的表征、锐钛矿: 金红石 $\mathrm{TiO}_{2}$ 相结 用于光催化产氢研究、 $\mathrm{TiO}_{2}$ 相结在光催化中作用的最新认识等.

在表征方面,通过表面灵敏的紫外拉曼光谱研究了 $\mathrm{TiO}_{2}$ 相变过程中表面相结构的变化, 结合可见拉曼以及XRD表征揭示了 $\mathrm{TiO}_{2}$ 独特的相变过程, 即相变始于锐铁矿粒子的界面处, 小粒子逐渐团聚为大粒子, 致其相变从大粒子体相开始最终扩展到整个 粒子. 使用 $\mathrm{CO}, \mathrm{CO}_{2}$ 探针红外光谱, 根据锐钣矿和金红石表面吸附物种的差异, 进一步证实了锐钣矿: 金红石表面相结结构, 为紫 外拉曼光谱的表面表征特性提供坚实证据. 同时, 利用发光光谱观察到锐钛矿晶相的可见发光带和金红石晶相的近红外发光带, 并基于此给出了 $\mathrm{TiO}_{2}$ 材料表面相结结构的荧光表征新方法. 此外荧光光谱还提供了锐钛矿、金红石相中载流子动力学信息, 揭示 了束缚态在光催化中的作用.

在光催化应用方面, 观察到混相结构 $\mathrm{TiO}_{2}$ 较单独锐针矿及金红石相具有更高的光催化产氢活性, 通过在较大金红石颗粒上担 载纳米锐钣矿粒子, 证明了相结结构在提高光催化活性中的核心作用, 并首次提出了锐钋矿: 金红石表面异相结结构概念, 推断 其对电荷分离的促进作用是最终提高反应活性的原因. 之后将此概念应用到改善商品 $\mathrm{TiO}_{2}(\mathrm{P} 25)$ 光催化活性中, 通过可控热处理 精细调控P25的表面相结构, 在光催化重整生物质衍生物产氢实验中, 成功将P25光催化产氢活性提高3-5倍. 之后发展了新的 $\mathrm{TiO}_{2}$ 表面控制方法, 通过加入 $\mathrm{Na}_{2} \mathrm{SO}_{4}$ 等相变控制剂, 延缓了 $\mathrm{TiO}_{2}$ 从锐铁矿向金红石的相变过程, 在较高温度下实现 $\mathrm{TiO}_{2}$ 相结结构 的调控, 最终可将P25光催化重整甲醇制氢的活性提高6倍, 同时通过高分辨电镜清晰观察到锐钣矿: 金红石相结的原子层生长接 触.

在相结作用机理方面, 多种时间分辨光谱技术以及理论计算被用作探索锐钛矿: 金红石相结处的电子转移机理. 通过时间分 辨红外光谱对 $\mathrm{TiO}_{2}$ 表面相结结构作用的研究, 特别是利用锐钣矿、金红石不同的瞬态吸收光谱特征, 证明了锐钛矿: 金红石相结 处的载流子转移过程, 存在锐钛矿向金红石的电子转移过程. 模型光催化剂 $\mathrm{TiO}_{2}$ 相结的研究成果, 加深了对光催化机理的认识, 促进新型高效光催化体系的设计合成.

关键词: 光催化; 表面相结; 电荷分离; 太阳能;二氧化钛

收稿日期: 2015-04-09. 接受日期: 2015-04-22. 出版日期: 2015-00-20.

*通讯联系人. 电话: (0411) 84379070; 传真: (0411) 84694447; 电子信箱: canli@dicp.ac.cn

基金来源: 国家自然科学基金(21203185); 国家重点基础研究发展计划(973计划, 2014CB239403).

本文的英文电子版由Elsevier出版社在ScienceDirect上出版(http://www.sciencedirect.com/science/journal/18722067).

\section{For Author Index:}

MA Yi, WANG Xiuli, LI Can 